\section{Antibiotika ved alvorlig underernæring hos barn}

\author{
Antibiotikabehandling av barn med akutt alvorlig underernæring \\ er assosiert med lavere dødelighet.
}

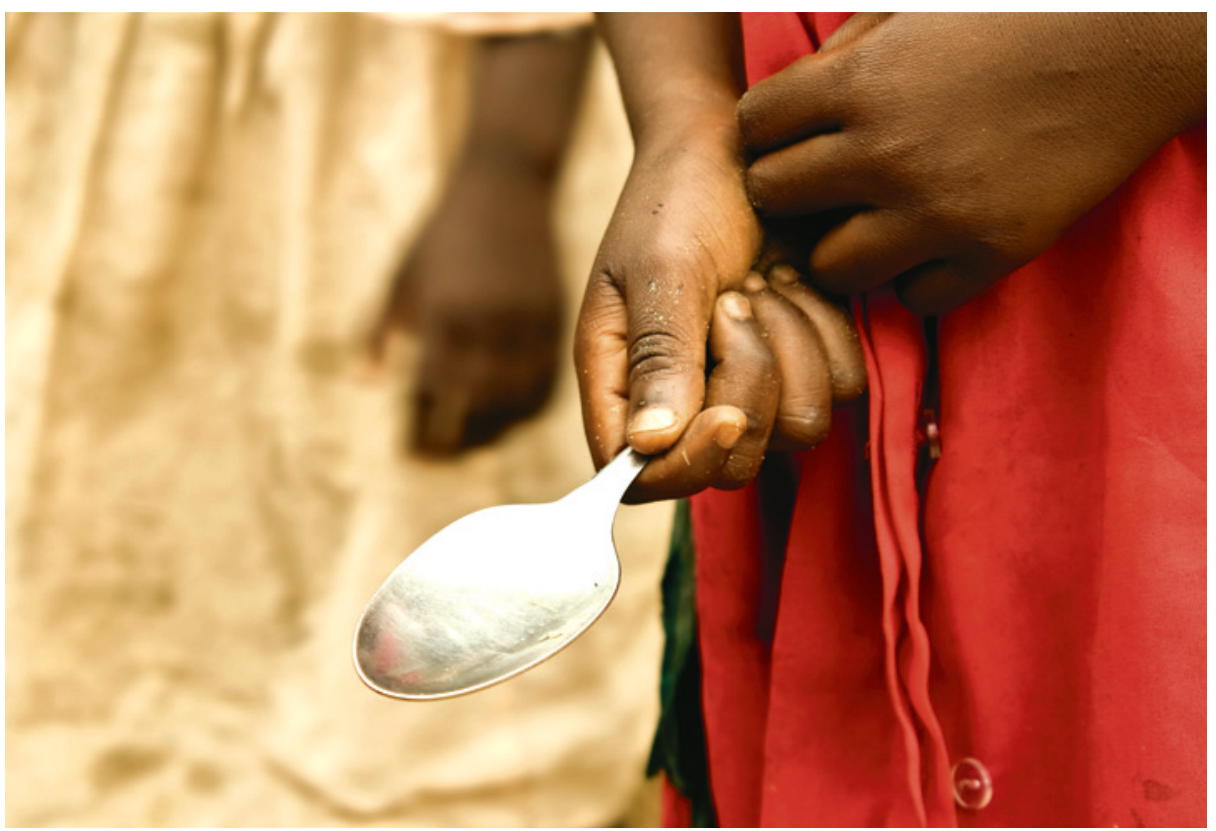

Illustrasjonsfoto Istockphoto

Det viser en ny studie fra Malawi, hvor man så på effekten av å gi antibiotika i tillegg til terapeutisk mat (Ready to use therapeutic food, RUTF) til barn med ukomplisert akutt alvorlig undernæring (1). 2767 malawiske barn i alderen 6-59 måneder ble randomisert til å motta amoksicillin, kefalosporinet cefdinir eller placebo i sju dager i tillegg til terapeutisk mat. I placebogruppen var dødeligheten $7,4 \%$, mens den hos barn som fikk amoksicillin eller cefdinir var henholdsvis $4,8 \%$ og $4,1 \%$.

Verdens helseorganisasjon anbefaler å gi antibiotika i tillegg til terapeutisk mat, også ved ukomplisert alvorlig akutt underernæring hos barn (1). - Selv om en fersk metaanalyse tyder på at kunnskapsgrunnlaget for en slik anbefaling er svak (2), vil jeg likevel tro at rutinemessig oral antibiotikabehandling ved akutt alvorlig underernæring nå vil bli akseptert som standarden. Dette vil skje til tross for en bekymring om $ø$ kt antibiotikaresistens, sier Ola Didrik Saugstad ved Pediatrisk forskningsinstitutt, Kvinne- og barneklinikken, Oslo universitetssykehus, Rikshospitalet.

\footnotetext{
Litteratur

1. Trehan I, Goldbach HS, LaGrone LN et al. Antibiotics as part of the management of severe acute malnutrition. N Engl J Med 2013; 368: 425-35. 2. Alcoba G, Kerac M, Breysse $S$ et al. Do children with uncomplicated severe acute malnutrition need antibiotics? A systematic review and metaanalysis. PLoS ONE 2013; 8: e53184.
}

\section{Mikro-RNA mot hjertesvikt?}

\author{
Kan hjertets pumpefunksjon \\ etter hjerteinfarkt reetableres \\ ved å sette i gang celledeling \\ i hjertemuskelceller?
}

Tradisjonelt har vi trodd at hjertemuskelcellene ikke deler seg etter fødselen. Hos forsøksdyr har man nå fått hjertemuskelceller til å dele seg via mikro-RNA-behandling (miRNA) (1). Hundrevis av forskjellige humane miRNA-molekyler ble testet i kulturer av hjerteceller fra nyfødte rotter og mus der celledelingen ikke var helt avsluttet, men kunne økes eller reduseres. Normalfunksjonen til miRNA er å hemme cellers budbringer-RNA (mRNA) slik at proteinsyntesen nedsettes. Hvilke cellulære proteiner som hindrer hjertecellene fra å dele seg, vet man ennå ikke.

To miRNA-er som økte celledelingene mest (mitose så vel som cytokinese, bestemt med fluorescensmikroskopi av indikatormolekyler), ble utforsket nærmere. Etter overføring til hjerter hos voksne dyr fant man celledeling i hjertemuskelcellene, men ikke i bindevevscellene. Etter hjerteinfarkt hos mus stimulerte miRNA-ene hjerteregenerasjon og gjenopprettet nesten normal pumpefunksjon. Kan man tenke seg miRNA-behandling av hjertesvikt innført i klinisk virksomhet, eller er andre, nye behandlingsmåter mer lovende?

- Bruk av stamceller, genterapi, bygging av nytt vev og økt forståelse av sebrafiskens evner til vevsregenerasjon er forskningsfelt som kan konkurrere med bruk av miRNA for å redde et skadet hjerte, sier professor Guro Valen, Avdeling for fysiologi, Institutt for medisinske basalfag, Universitetet i Oslo.

- Stamceller og genterapi kom til klinisk prøving for tidlig og trenger mer tid i laboratoriet. Med miRNA har vi utfordringer med leveransemåte, preparatets stabilitet og farmakologisk produksjon av syntetiske midler. Vår forståelse av grunnleggende biologiske forhold er også mangelfull. Jeg tror ikke at miRNA-behandling av hjertesvikt vil skje i overskuelig fremtid, sier Valen.

\section{Haakon B. Benestad}

h.b.benestad@medisin.uio.no

Universitetet i Oslo

\section{Litteratur}

1. Eulalio A, Mano M, Dal Ferro M et al. Functional screening identifies miRNAs inducing cardiac regeneration. Nature 2012; 492: 376-81. 